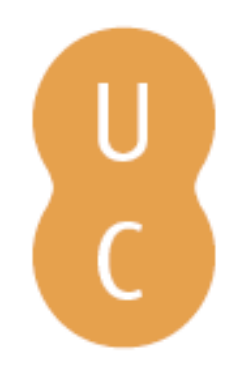

\title{
nommalina
}

\section{Effective efficiency index (IEE): methodology for analyzing the efficiency of fire retardants in laboratory}

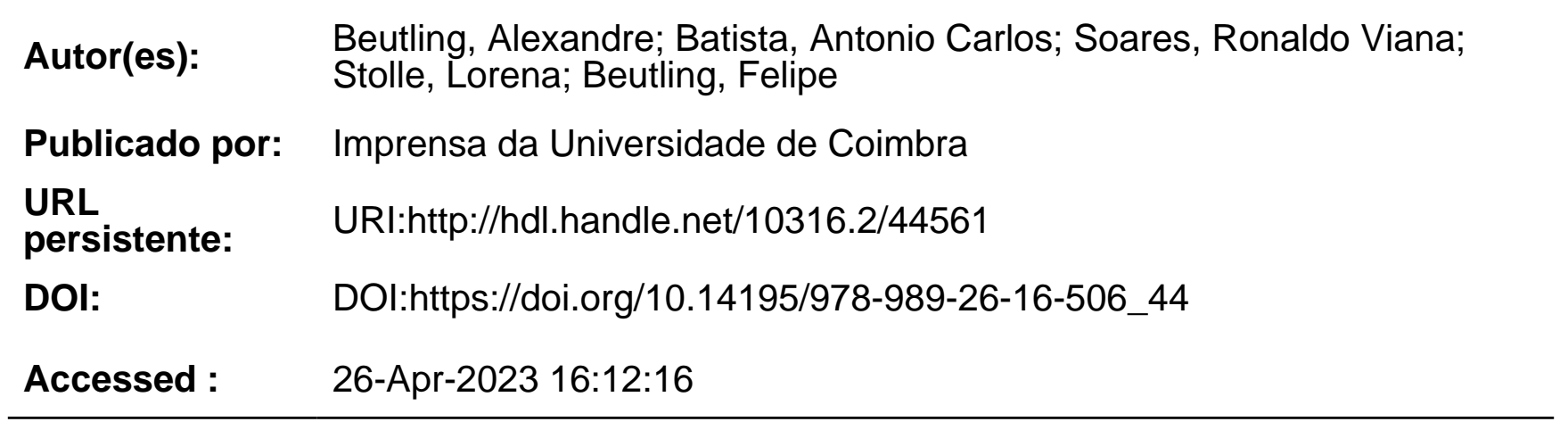

A navegação consulta e descarregamento dos títulos inseridos nas Bibliotecas Digitais UC Digitalis, UC Pombalina e UC Impactum, pressupõem a aceitação plena e sem reservas dos Termos e Condições de Uso destas Bibliotecas Digitais, disponíveis em https://digitalis.uc.pt/pt-pt/termos.

Conforme exposto nos referidos Termos e Condições de Uso, o descarregamento de títulos de acesso restrito requer uma licença válida de autorização devendo o utilizador aceder ao(s) documento(s) a partir de um endereço de IP da instituição detentora da supramencionada licença.

Ao utilizador é apenas permitido o descarregamento para uso pessoal, pelo que o emprego do(s) título(s) descarregado(s) para outro fim, designadamente comercial, carece de autorização do respetivo autor ou editor da obra.

Na medida em que todas as obras da UC Digitalis se encontram protegidas pelo Código do Direito de Autor e Direitos Conexos e demais legislação aplicável, toda a cópia, parcial ou total, deste documento, nos casos em que é legalmente admitida, deverá conter ou fazer-se acompanhar por este aviso.

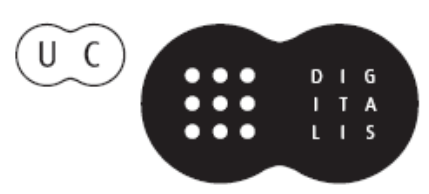




\section{ADVANCES IN}

\section{FOREST FIRE RESEARCH}

\section{8}

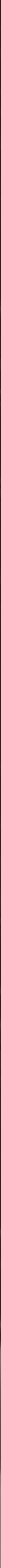




\title{
Effective efficiency index (IEE): methodology for analyzing the efficiency of fire retardants in laboratory
}

\author{
Alexandre Beutling ${ }^{1 *}$; Antonio Carlos Batista ${ }^{2}$; Ronaldo Viana Soares ${ }^{2}$; Lorena Stolle ${ }^{1}$; Felipe \\ Beutling ${ }^{3}$ \\ ${ }^{1}$ Universidade Federal de Mato Grosso do Sul. Rodovia MS-306 - Zona Rural, Chapadão do Sul - \\ MS, 79560-000, \{beutling.a@gmail.com*,lorenastolle@yahoo.com.br\} \\ ${ }^{2}$ Universidade Federal do Paraná. CIFLOMA. Av. Pref. Lothário Meissner, 632, 80210-170 - \\ Jardim Botânico - Curitiba - PR \{batistaufpr@ufpr.br; rvsoares02@gmail.com\} \\ ${ }^{3}$ Eng. Florestal Felipe Beutling. Rua 7 de Setembro, 1865 - Sala 3 - Centro, Blumenau - SC, \\ 89012-401, \{felipe.beutling@gmail.com\}
}

\begin{abstract}
In Brazil, fire retardants for forest fire prevention and suppression are seldom used. However, these products can be found in the market, and there are some records of their use. There are also many researches dealing with efficiency evaluations of retardants, using different methodologies. Thus, this research aims to present a standard protocol which can be used by different researchers and orient the professionals who use this type of product in their daily activities. This protocol derives from an improvement of a methodology for evaluating the efficiency of retardants, based on fire behavior analysis in tests carried out in the laboratory. The Effective Efficiency Index (IEE) can be used in different assessment scenarios. With the aid of a preconfigured data processing worksheet, the IEE will facilitate the evaluation of fire retardants in laboratory, as well as to provide a way to compare different formulations and concentrations of many products available in the market.

In addition, to refine the results and establish the level of approval, "classification criteria" were created, which provides a distinguished interpretation and allows the comparison of different retardants and concentrations, regardless of their "retardant" or "suppressor " effects (i.e. a retardant that provides only "retardant" effect in the laboratory does not necessarily means that it will be less effective than a product that provides a "fire suppressor" result).

To develop the methodology, more than 1000 replicates were conducted in laboratory, using different fire retardants formulations, between 2006 and 2010. In 2018, for the improvement of the methodology (called IEE) and its validation, 250 replicates were conducted with different retardants, concentrations and densities, plus control (plain water). Results showed that the values of the efficiency indices resulting from the tests allows a good estimation of the action (or response) of the fire retardants in field conditions for forest fires control activities.
\end{abstract}

Keywords: Fire retardant, forest fire, fire control, forest protection

\section{The Use of Fire Retardants in Brazil}

In Brazil, the use of long term chemical retardants in the control of forest fires is still incipient, occurring only in some private companies and in emergency situations from the federal government. Although fire retardants have been heavily used in many regions of the world, being considered a fundamental tool in fire control activities, in Brazil there is no regulations or legal provisions which establish criteria to evaluate such products, as well as standard procedures for their use. This gap makes difficult the use of these products and restrains the refinement of the suppression techniques aimed to reduce the extension of damages and burned areas in the country.

Fire retardants are chemical products that reduce or impede the fuel combustion, increasing the water efficiency in fire suppression activities (Ribeiro et al, 2006). Many researchers (Pastor, 2004; 
Ribeiro et al., 2006; Ribeiro, 2006; Batista, 2008; Beutling et al, 2008; Vázquez, 2011; Vieira, 2011; Machado Filho et al, 2012; Canzian, 2013; Fiedler et al, 2015) have dedicated efforts performing laboratory and field tests in order to evaluate the effectiveness of retardants from different companies.

The objective of this research was to improve a standard methodology to evaluate the efficiency of fire retardants in laboratory conditions, as a tool to help forest managers to take decisions when dealing with fire control activities.

\section{Methodology}

The proposed methodology included three steps, as follows:

1 - Utilizes an adaptation of the Global Efficiency Index (Ie), proposed by Ribeiro et. al. (2006) - evaluation of the "retardant" effect, which describes the outcome of flames high and fire speed reduction, without extinguishing the fire front.

2 - Utilizes a variable called "hammer effect" (EfM), which evaluates the retardant efficiency to suppress the fire front as soon as it reaches the area where the retardant was applied. This variable takes in account two factors: extinction time (TE) and the average penetration distance $(\mathrm{P})$ of the fire in the retardant application area, both in percentage. The calculation of these two factors was based in the measured time and the dimension of the application area.

3 - For the calculation of the "Effective Efficiency Index (IEE)", which establishes a relationship between (Ie) and (EfM), a multiplication factor called "result valorization" and a "scale adjustment" were used, in such way that "retardant" results never exceeds $70 \%$ in the (IEE) scale, and the results "Fire suppressor" can use the full scale range (from 0 to 100).

In addition, to refine the results and establish the level of approval, "classification criteria" were created, which provides a distinguished interpretation and allows the comparison of different retardants and concentrations, regardless of their "retardant" or "suppressant " effects (i.e. a retardant that provides only "retardant" effect in the laboratory does not necessarily means that it will be less effective than a product that provides a "fire suppressant" result). Figure 1 show the flow chart designed to evaluate the (IEE).

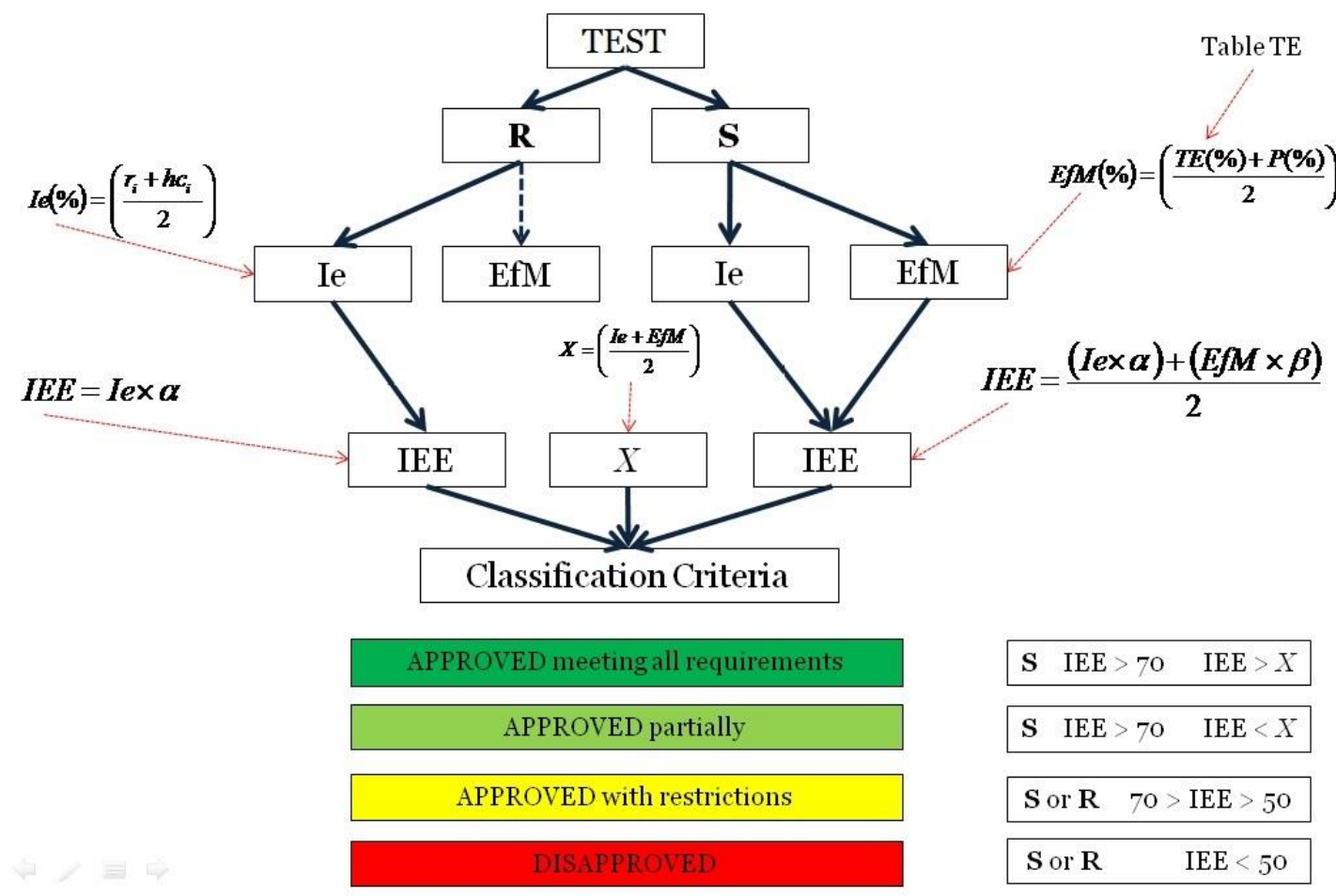

Figure 1 - Flow chart designed to evaluate the Effective Efficiency Index 
Descriptively, a test-formulation (FTn) in certain concentration, is submitted to the efficiency evaluation procedure (TESTE) in a standard burning (QP), whose result could be a retardant (R) or a suppressing (S) effect. The IEE value was calculated according the two following conditions:

a. When the effect is retardant $(R)$ : In this case, there is no suppressant effect and, consequently, the "hammer effect" (EfM) is zero. The index that evaluates the retardant potential of the product is the (Ie), which analyses the product efficiency on the flames height and rate of spread reduction in the following way:

$$
\begin{gathered}
\frac{\mathrm{VPMC}}{\mathrm{VPMS}}=\mathrm{RVP} \\
(1-\mathrm{RVP}) * 100=\mathrm{r}_{\mathrm{i}} \\
\frac{\mathrm{HMCC}}{\mathrm{HMCS}}=\mathrm{RHC} \\
(1-\mathrm{RHC}) * 100=\mathrm{hc}_{\mathrm{i}} \\
\mathrm{Ie}=\frac{\mathrm{r}_{\mathrm{i}}+\mathrm{hc}_{\mathrm{i}}}{2}
\end{gathered}
$$

Where:

VPMC $=$ Average rate of spread in plots treated with retardant;

VPMS = Average rate of spread in plots without retardant;

$\mathrm{RVP}=$ Rate of spread reduction;

$r_{i}=$ Percentage of rate of spread reduction;

$\mathrm{HMCC}=$ Average flames height in plots treated with retardant;

HMCS = Average flames height in plots without retardant;

RHC = Flame height reduction;

$\mathrm{hc}_{\mathrm{i}}=$ Percentage of flames height reduction;

Ie = Efficiency index;

b. When the effect is suppressant (S): In this case, the hammer effect (EfM) is calculated as follows:

$$
\frac{\% \mathrm{TE}+\% \mathrm{P}}{2}=\mathrm{EfM}
$$

Where:

$\% \mathrm{TE}=$ Extinction time in percentage - it is the time for complete extinction of the fire front inside the area where the product was applied. It is based in a relationship between time intervals (in seconds) and a percentage value of efficiency loss for each 10 seconds of active fire front, i.e., that the fire front remains lit.

$\% \mathrm{P}=$ Penetration distance in percentage - refers to the distance traveled by the fire front inside the area where the product was applied. It is the relationship between the linear distance (in $\mathrm{cm}$ ) and a percentage value of efficiency loss (for each centimeter travelled by the fire front inside the area, $1 \%$ efficiency loss is accounted). If $\mathrm{P}$ is equal to the total area length (which must be $100 \mathrm{~cm}$ maximum), $\% \mathrm{P}$ is equal to zero.

An average $(\mathrm{X})$ between the (Ie) and the (EfM) values should be calculated to help in the (FTn) framing in the classification criteria: 


$$
\frac{\mathrm{Ie}+\mathrm{Efm}}{2}=\mathrm{X}
$$

Based on the calculations presented before, the Effective Efficiency Index (IEE) is estimated, considering also:

i. Utilization of coefficients $\alpha$ e $\beta$ for adjusting the scale (rule) to the Classification Criteria, in order to enhance the suppressant values (EfM), and lower the retardant (Ie) values. Those coefficients should be multiplied to the (Ie) and to the (EfM).

ii. If the test result indicates a Retardant effect, the (IEE) will be the product of the (Ie) multiplied by the coefficient $\alpha$. If the (IEE) is higher than $50 \%$ the product is "Approved with Restrictions (YELLOW), otherwise it will be Reproved (RED)

$$
I e \times \alpha=I E E
$$

iii. If the test result indicates a Suppressant effect, the (IEE) is calculated as follows:

$$
\frac{(I e \times \alpha)+(E f M \times \beta)}{2}=I E E
$$

Where:

$\alpha=0,714285714285714 \ldots$

Obs: $\mathrm{Ie}=70 \%$ is the lower value for a product be approved as a Retardant ( $70 * \alpha=50$ ).

$\beta=1,285714285714285 \ldots$

$\beta=1+(1-\alpha)$

When the (IEE) is equal or higher than $70 \%$, the product will be declared "Approved considering partially the exigencies (LIGHT GREEN) if the (IEE) is lower than (X), or "Approved considering all the exigencies (DARK GREEN) if the (IEE) is higher than (X)

Summarizing, the Classification Criteria were established in the following way:

i. Suppressant, with (IEE) higher than (X): Approved considering all the exigencies (DARK GREEEN);

ii. Suppressant, with (IEE) lower than (X): Approved considering partially the exigencies (LIGHT GREEN);

iii. Suppressant or Retardant, with 70>(IEE) $>50$ : Approved with restrictions (YELLOW);

iv. Suppressant or Retardant, with (IEE) lower than 50: "Reproved (RED);

\section{Additional comments:}

The laboratory test result "Approved considering all the exigencies" indicates a strong possibility that the fire retardant presents suppressing effects in field conditions.

The (IEE) is very sensible to concentration and formulation variations, and directly dependent upon good laboratory practices (regarding the procedures related to the fuel bed assemblages, the product application, and the measurements made). For all those reasons, it needs a well trained professional for its execution.

To develop the methodology, more than 1000 replicates were conducted in laboratory, using different fire retardants formulations, between 2006 and 2010 (Beutling, 2007). For the improvement 
of the methodology (called IEE) and its validation, 250 replicates were conducted with different retardants, concentrations and densities, plus control (plain water). Fire behavior data from the areas with and without retardants were stored and processed using the softwares Excel 2003 and Statgraphics Centurion XV.

The IEE could be used in different scenarios and evaluations. Using a data processing customized platform, the IEE would make easier the retardant evaluation in laboratory environment. The IEE would be valuable also to compare different formulations and concentrations of the several products found in the market.

\subsection{Characteristics of the "Standard-Burn (QP)"}

The proposed laboratory conditions to carry out the burning tests are:

a) Fuel bed dimensions: for the IEE methodology, the fuel bed size does not interfere in the results. However, considering favorable logistic questions, it is recommended fuel bed with $1.5 \mathrm{~m}$ long, $0.75 \mathrm{~m}$ wide, divided in $10 \mathrm{~cm}$ intervals. The initial $10 \mathrm{~cm}$ are reserve to the ignition (fire start), and the final $10 \mathrm{~cm}$ to the fire stopping; in the central area, the first $80 \mathrm{~cm}$ are considered the area of free propagation (A.S - without product), and the following $50 \mathrm{~m}$ are reserved to the application of the tested retardant, called application area (A.C - with product) (Figure 2).

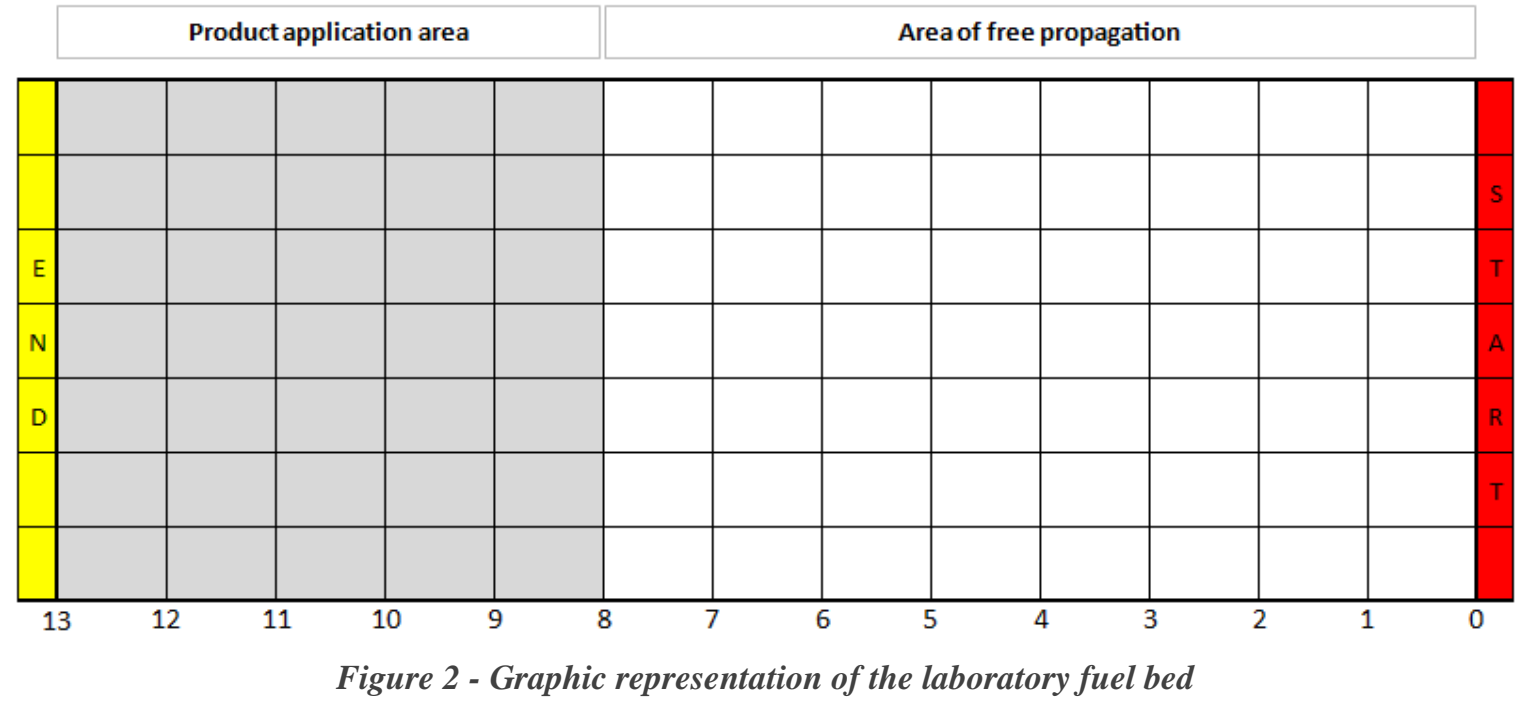

b) Successive burns: it is a succession of 5 replications of each treatment that should be burned sequentially in the same day.

c) Time of burning: the burns should start after 10:00AM and, preferentially, not progress after 4:00PM (in the proposed fuel beds dimensions the total time to carry out the 5 burns may not take more than 3 hours).

d) Ideal environment: the tests should be carried out in laboratory environment, with exhaustion system, without the interference of external climatic conditions. The local must be closed, in order to maintain a minimum thermal and relative humidity variation and avoid wind interference. Laboratory doors and windows must be closed during the tests. Usually, the first burning tends to be slower, due to the lower temperature and higher relative humidity. Those conditions may change during the burnings. For this reason it is advisable to carry out calibration burns that would balance the laboratory environment.

e) Fuel: the best combustible material is probably "tifton" hay, (it can be easily found in agriculture shops). The fuel must be stove dried at $80^{\circ} \mathrm{C}$ for at least 12 hours before utilization. Twenty four hours would be even better, because when stored in great volumes the process of drying is not homogeneous, interfering in the moisture content: 
i. The fuel load should be $1.0 \mathrm{~kg} . \mathrm{m}^{2}$, evenly distributed over the fuel bed;

ii. The recommended thickness of the litter (hay) is 8.0 to $9.0 \mathrm{~cm}$. Thickness lower than $7.0 \mathrm{~cm}$ increases the density and affects the product application. Besides that, it interferes in the fire behavior; flames height is lower, and fire spread too slow;

f) The recommended volume of the product to be tested is $0.51 . \mathrm{m}^{2}$, regardless the concentrations to be evaluated.

g) Application equipment: a pressurized manual atomizer, of low operational cost, is recommended. It should permit evaluating characteristics like viscosity and density of the solution during the application.

h) General procedure: the burning should be carried out the day after the fuel assemblage and product application. This is necessary to avoid the influence of water in the test result; in preliminary tests using only water the observed (IEE) was $9.8 \%$. Thus, in the day before the burning, the following procedures should be observed:

i. Take the fuel (hay) out from the oven;

ii. The fuel is weighted and evenly distributed over the fuel bed;

iii. A sample of the oven dried fuel is taken, weighted, and placed in a tray to be weighted again in the next day, before the burning. It is recommended to weigth 5 trays to estimate the moisture increment from the fuel assemblage in the fuel beds up to the burning time.

iv. The product (retardant) must be applied always the same way, according to the following sequence (position - direction):

- left side - from the front line to the end zone;

- end zone - from left to right;

- right side - from the end zone to the front line;

- midle - in zigzag from the right to the left, moving from the end zone to the front line;

- during the application, in each position-direction, the product should be applied only once, up to the end of the passages. If a gap is detected, it could be covered later, with the remaining product in the atomizer (it is not advisable to go back to cover the gap before finishing the application, because it could fail short of product to cover the whole area).

\subsection{Application of the IEE: a case study}

In order to exemplify the IEE application the efficiency of a fire retardant in concentrations of 5, 10,15 and $20 \%$ was carried out. The burnings were conducted in a fuel bed $1.48 \mathrm{~m}$ long and $0.76 \mathrm{~cm}$ wide. The measurements were made every $10.0 \mathrm{~cm}$ of fire progress, in a total of 40 replications (10 for each concentration). All fire behavior information was stored in the (IEE) data processing platform. The results of the retardant efficiency according to the used concentration are presented in Figure 3. 


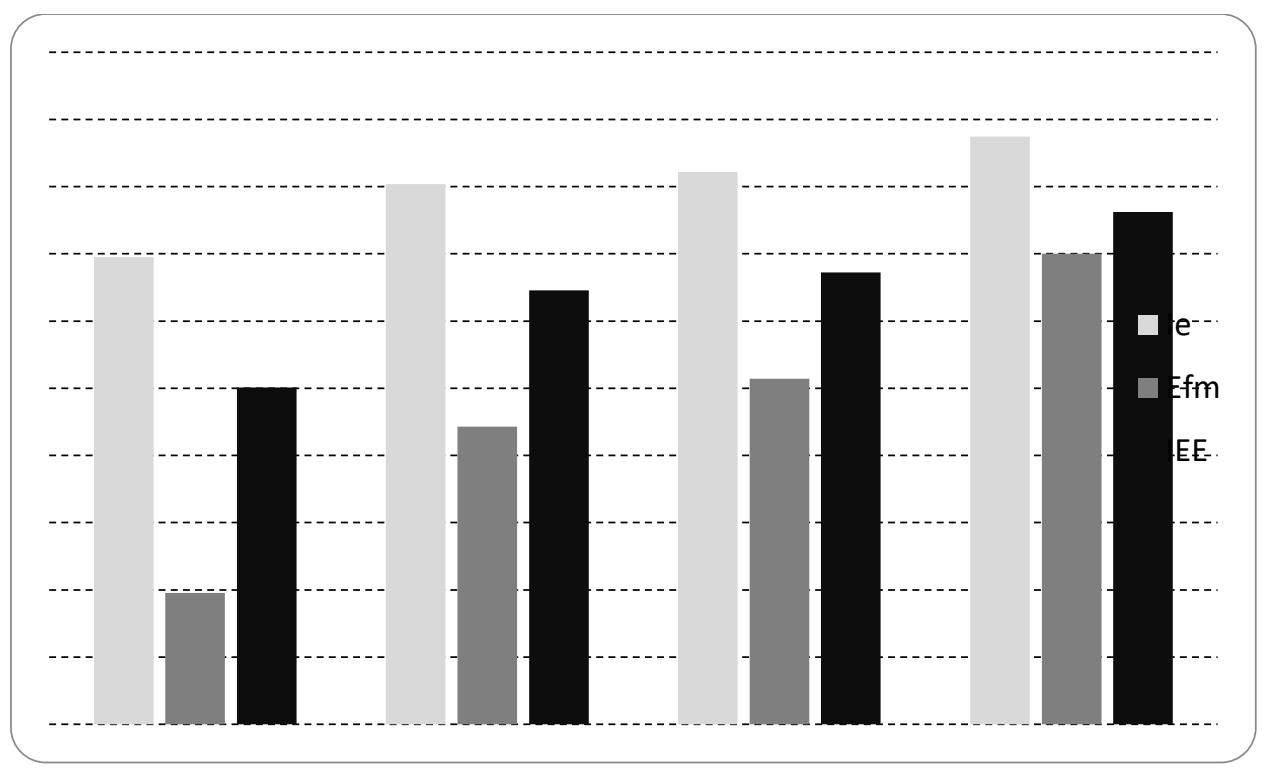

Figure 3 - Effective Efficiency Index (IEE) for the different concentrations of the fire retardant

The analyzed fire retardant presented good efficiency, even in the concentration of 5\%, reducing the flame height in $60.29 \%$ and the fire speed in $78.79 \%$, with an (IEE) equal to $50.15 \%$. In the $20 \%$ concentration, the (IEE) was $76.22 \%$, corresponding to $84.46 \%$ reduction in the flame height and $90.39 \%$ reduction in the fire speed. Regarding the relationship "retardant x suppressant", only the $20 \%$ concentration was $100 \%$ suppressor.

\section{Conclusions}

\subsection{Regarding the IEE}

The (IEE) is quite sensible to the efficiency variation of the retardants, and because it presents a finite scale (0 to $100 \%$ ), makes possible the comparison of different products, as well as the efficiency rating due to different concentrations.

The index allows the analysis of retardants efficiency along the time, i.e., several days after the application, what helps in the determination of how long the product maintains its efficiency.

The IEE can be useful on the developing of different retardant formulations, tests of raw materials, and quality control.

\subsection{Regarding the case study}

For direct attack to the fire, the $5 \%$ concentration of the tested retardant is recommended;

For indirect attack or fire prevention, the $20 \%$ concentration is recommended.

\section{References}

Batista, A. C. et al. Avaliação da eficiência de um retardante de longa duração, à base de polifosfato amônico, em queimas controladas em condições de laboratório. Scientia Forestalis, Piracicaba, v.36, n.79, p. 223-229, set. 2008.

Beutling, A. Índice de eficiência efetiva (i). Manual do Laboratório de Pesquisa e Controle de Incêndios (LPCI Rio Sagrado). Não publicado. 2007.

Beutling, A. et al. Propuesta de metodologia de evaluación de retardantes químicos en unidades de muestreo artificiales de campo. In: V Simposio Internacional sobre Manejo Sostenible de los 
Recursos Forestales - SIMFOR, 2008, Pinar del Río. Memórias del V Simposio Internacional sobre Manejo Sostenible de los Recursos Forestales-SIMFOR 2008, 2008. v. 1. p. 1-11.

Canzian, W. P. Análise da eficiência de retardantes de fogo em testes de laboratório. Monografia. Universidade Federal do Espírito Santo. 16p.

Fiedler, N. C. et al. Intensidade de queima de diferentes retardantes de fogo. Revista Árvore, Viçosa, Minas Gerais, v. 39, n. 4, p. 691-696, 2015.

Machado Filho, C. et al. Eficiência de um retardante de fogo de longa duração utilizado em incêndios florestais. Ciência Florestal, Santa Maria, v.22, n.2, p. 365-371, abr-jun. 2012.

Pastor F. E. Contribució a l'estudi dels efectes dels retardants en l'extinció d'incendis forestals. 2004. 304 p. Tese (Doutorado) - Centre de Estudis del Risc tecnològic, Departament d'Enginyeria Química, Escola Tècnica Superior d'Enginyeria Industrial de Barcelona, Barcelona, 2004

Ribeiro, L.M. Viegas, D.X. batalha, M. Assessment of fire retardant efficiency. Portugal, 2006. 11f. in "V International Conference on Forest Fire Research". CD.

Ribeiro, G. A. et al. Eficiência de um retardante de longa duração na redução da propagação do fogo. Revista Árvore, Viçosa, Minas Gerais, v. 30, n. 6, p. 1025-1031, nov./dez. 2006.

Vásquez, A. C. El ciclo del $\mathrm{N}$ em sistemas agroforestales: Evaluación isotópica $\left({ }^{15} \mathrm{~N}\right)$ em tres tipos de manejo. Santiago de Compostela, 2011. Tesis. Universidade de Santiago de Compostela. 241p.

Vieira, F. I. Combate a incêndio florestal: determinação do índice de eficiência global de retardantes químicos de curta e de longa duração e avaliação de seus efeitos sobre a redução da intensidade do fogo em vegetação em condições de laboratório. Monografia. Florianópolis: CEBM, 2011. 78 f. 